\title{
Multicolor flow cytometry analysis of innate responses following in vitro interaction of PBMC with Hepatitis C virus
}

\author{
Françoise Gondois-Rey, Diana Herrera, Daniel Olive, Ivan Hirsch* \\ From $16^{\text {th }}$ International Symposium on HIV and Emerging Infectious Diseases \\ Marseille, France. 24-26 March 2010
}

\section{Background}

Alterations in innate immunity responses might be implicated in the establishment of a chronical infection with hepatitis $\mathrm{C}$ virus (HCV) in more than $80 \%$ of infected patients. This hypothesis is supported by the relative success of IFN-alpha-based therapy. Our aim has been to evaluate the consequences of HCV interaction with PBMC on global innate immune functions and to compare it to interaction with other RNA viruses, influenza and HIV-1.

\section{Methods}

The complex setting and diversity of interactions among cellular sub-populations involved in the innate response was approached by a short-time virus stimulation of total PBMC population. Multicolor cytometry is a unique tool for these multi-parametric investigations. By the mean of a 17-color LSRII, we have identified simultaneously plasmacytoid dendritic cells (pDCs), myeloid dendritic cells (mDCs), NK, monocytes and CD8+ T lymphocytes and analyzed their functional response to virus stimulation by measurment of expression levels of activation markers (CD69, CD83, CD86) and intra-cellular cytokines (IFN-alpha, IFN-gamma, TNF-alpha, IL-12).

\section{Results}

The global overview of the functional markers expression in each cell sub-population shows differences between the RNA viruses tested. Influenza induces pDC and NK activations but not the activation of $\mathrm{mDC}$ and monocytes. Interistingly, responses to $\mathrm{HCV}$ and HIV clusterize together and are characterized by a sustained

\footnotetext{
* Correspondence: ivan.hirsch@inserm.fr

INSERM, UMR891, Centre de Recherche en Cancérologie de Marseille and Institut Paoli-Calmettes, and Université Méditerranée, Marseille, France
}

IL-12 production in $\mathrm{mDC}$ and monocytes associated to a low pDC and NK activation. HCV-infected patients cells show a lower response to TLR7/8 agonist or HCV re-stimulation as compared to uninfected donors.

\section{Discussion}

In conclusion, with the help of multicolor cytometry technology, we were able to take a time-dependant picture of innate immune responses to RNA viruses stimulations from a complex cell system. Our results show importance of $\mathrm{mDCs}$ for a deeper understanding of $\mathrm{HCV}$ interactions with the innate immunity. (ANRS grant 2007/306)

Published: 11 May 2010

doi:10.1186/1742-4690-7-S1-P8

Cite this article as: Gondois-Rey et al:: Multicolor flow cytometry analysis of innate responses following in vitro interaction of PBMC with Hepatitis C virus. Retrovirology 2010 7(Suppl 1):P8.
Submit your next manuscript to BioMed Central and take full advantage of:

- Convenient online submission

- Thorough peer review

- No space constraints or color figure charges

- Immediate publication on acceptance

- Inclusion in PubMed, CAS, Scopus and Google Scholar

- Research which is freely available for redistribution

Submit your manuscript at www.biomedcentral.com/submit
Biomed Central 